University of Michigan Law School

University of Michigan Law School Scholarship Repository

Articles

Faculty Scholarship

1912

\title{
Possession under Mistake as Adverse Possession
}

Ralph W. Aigler

University of Michigan Law School

Available at: https://repository.law.umich.edu/articles/1089

Follow this and additional works at: https://repository.law.umich.edu/articles

Part of the Property Law and Real Estate Commons, and the State and Local Government Law Commons

\section{Recommended Citation}

Aigler, Ralph W. "Possession under Mistake as Adverse Possession." Mich. L. Rev. 11 (1912): 57-8.

This Response or Comment is brought to you for free and open access by the Faculty Scholarship at University of Michigan Law School Scholarship Repository. It has been accepted for inclusion in Articles by an authorized administrator of University of Michigan Law School Scholarship Repository. For more information, please contact mlaw.repository@umich.edu. 
Possession UNDER Mistake as Adverse Possession.-In Wissinger v. Reed et al., I25 Pac. 1030 (Aug. 24, I9I2) the Supreme Court of Washington held that actual possession of land for the statutory period would confer title upon the occupant, although the possession was under a mistaken belief of ownership. While the doctrine that title to real property may be acquired by adverse possession has been firmly established in English and American law for a great many years, no little difficulty and confusion have arisen in determining what possession is adverse, especially where the actual possession upon which the claim of title is based has been under a mistaken belief that the land so occupied was properly in the possession of the claimant as owner.

Perhaps the most frequently cited case in this country on this matter is French v. Pearce (183I) 8 Conn. 439. In that case the lower court had instructed the jury that if the defendant had occupied the tract in dispute for the statutory period, but claiming and intending to occupy only to the true line, then his possession must be referred to his deed, and was not adverse. The Connecticutt court, in reviewing the case, held the charge erroneous, and laid down the doctrine that to constitute adverse possession it was sufficient that the claimant had occupied the land as his ozer. In a great many cases the doctrine of French v. Pearce, that the fact of the possession having been under such a mistaken belief does not prevent the possession from being considered adverse, has been approved and followed. But the courts following the rule of French v. Pearce in that regard refuse to follow it to the extent of holding that the possession under mistake is adverse even though the occupant is shown to have intended to claim only to the true line. In other words, in those courts professing to follow French v. Pearce there has been a modification of its doctrine which makes the rule substantially in accord with the instruction by the lower court in that case. Stirling v. Whitlow, 80 Ark. 444; Goodzwin v. Garibaldi, 83 Ark. 74; Shotwell v. Gordon, I2I Mo. 482; Richardson v. Watts, 94 Mo. 476; McDonald v. Fort, 20 Nev. 364; Thornley' v. Andrezes, 45 Wash. 413; Ayers v. Reidel, 84 Wis. 276 ; Edwards v. Fleming, 83 Kans. 653,33 L. R. A. N. S. 923; Silver Creek Cement Co. v. Union Lime \& Cement Co., I38 Ind. 297; Humes v. Bernstein, 72 Ala. 546; Pollit v. Bland, I5 Ky. L. Rep. 227; King v. Brigham, 23 Ore. 262; Fieldhouse v. Leisburg, 15 Wyo. 207; Brozen v. Clark, 73 Vt. 233 (dictum); Schaubuch v. Dillenmuth, 108 Va. 86, 15 A. \& E. Am. Cas. 825. The doctrine of French v. Pearce has been approved by the Connecticut court in the late case of Searles v. De Ladson, 8I Conn. I33.

On the other hand, in Grube v. Wells (187I) 34 Ia. 148, the Iowa supreme court held that mere possession as though the occupant were the owner, if under a mistake as to the true boundary line, was not adverse to the real owner, and title could not be acquired upon the strength of such possession. The doctrine of the Iowa court in that case would seem to require intentional occupancy of the land of another in order to have a case of adverse possession, and because the doctrine seems to place a premium upon conscious wrongdoing it has been criticized not a little. In Doolittle v. Bailey, 85 Ia. 398 , the Iowa rule was somewhat clarified by a holding to the effect that the possession is adverse if the occupant claims the land occupied as his own 
regardless of whether it shall ultimately be shown that there was a mistake in the boundary. With that modification the rule of Grube v. Wells has been adopted by a number of courts.

When the mere actual occupancy is insufficient, and it becomes a question of the intention of the occupant, the difficulties are obvious, and the result is that most of the cases are decided upon the application of one of two presumptions. The courts following what we may designate as the Iowa rule apply the presumption that the possession is subordinate to the paper title. Lecroix v. Malone, I57 Ala. 434; Barret v. Kelley, I3I Ala. 378; Williants v. Bernstein, 5I La. Ann. II5; Edwards v. Fleming, 83 Kans. 653; Preble v. Maine C. R. Co., 85 Me. 260; Kirkman v. Brozen, 93 Tenn. 476; Treece v. Am. Assoc., I22 Fed. 598 (applying Tennessee law). But the great weight of authority is to the contrary, and the trend of the late decisions is certainly to the effect that the possession, though under a mistake, is presumed to be not subordinate to the real owner. Johnson v. Elder,92 Ark. 30; Searles v. De Ladson, 8I Conn. 133; O'Flaherty v. Mann, 196 Ill. 304; Krause v. Nolte, 217. Ill. 298, 3 A. \& E. Ann. Cas. 106r; Dyer v. Eldridge, I36 Ind. 654; Diers v. Ward, 87 Minn. 475 ; Andrews v. Hastings, 85 Neb. 548; Sommer v. Compton, 52 Ore. I73; Bruce v. Washington, 8o Tex. 368; Hesser v. Seipman, 35 Wash. 14; Cole v. Brunt, 35 U. C. Q. B. I03; Lucas v. Provinces, I30 Cal. 270; Milligan v. Fritts, 226 Mo. I89; Johnson v. Thomas, 23 App. D. C. I4I.

Both of these rules being founded upon presumptions, evidence is admissible in practically all cases to rebut the presumption and to show the real nature and extent of the claim of the occupant. Schaubuch v. Dillenmuth, 108 Va. 86 , 60 S. E. 745 , is interesting along this line. Often the evidence is such that it is difficult to decide the character of the claimant's possession, whether he is claiming only to the true line, wherever it may be determined to be, or to the disputed boundary at all events, whether correct or not. In Johrson v. Thomas, supra, an ignorant colored woman became entitled under a certain will to a tract of land, eight acres in extent. She enclosed and occupied for the statutory period eleven acres. In an action for the possession of the three acres she claimed title thereto by adverse possession. The evidence showed that she had said repeatedly that all she wanted and claimed was what the will gave her, but she said that the will gave her the entire tract which she had occupied, and she insisted rupon this claim despite, the fact that repeated surveys showed her to be wrong. The court held that she was claiming the entire tract of eleven acres whether the line was correct or not. See also along the same line, Cole v. Parker, to Mo. 372. R. W. A. 